\title{
Citreicella aestuarii sp. nov., isolated from a tidal flat
}

\author{
Moon Su Park, ${ }^{1}$ Bok-Sil Chung, ${ }^{1}$ Hyo Jung Lee, ${ }^{1}$ Hyun Mi Jin, ${ }^{1}$ \\ Sang-Suk Lee, ${ }^{2}$ Young Kyoon $\mathrm{Oh}^{3}$ and Che Ok Jeon ${ }^{1}$ \\ ${ }^{1}$ Department of Life Science \& Research Center for Biomolecules and Biosystems, \\ Chung-Ang University, Seoul, 156-756, Republic of Korea \\ ${ }^{2}$ Department of Animal Science \& Technology, Sunchon National University, Sunchon 540-742, \\ Republic of Korea \\ ${ }^{3}$ Animal Nutrition \& Physiology Division, National Institute of Animal Science, RDA, Suwon, \\ 441-706, Republic of Korea
}

Correspondence

Che Ok Jeon

cojeon@cau.ac.kr

\begin{abstract}
A Gram-negative bacterium, designated $\mathrm{AD}^{\top}{ }^{\top}$, was isolated from a tidal flat of the Taean coast in South Korea. Cells were strictly aerobic, motile, ovoid rods or rods, with two lateral flagella on one side. Strain $A D 8^{\top}$ was catalase- and oxidase-positive and able to oxidize thiosulfate and reduce nitrate to nitrite. Growth of strain $\mathrm{AD}^{\top}$ was observed at $15-40{ }^{\circ} \mathrm{C}$ (optimum $25-30{ }^{\circ} \mathrm{C}$ ), at $\mathrm{pH}$ 5.0-9.5 (optimum $\mathrm{pH}$ 6.0-7.5) and with 1.0-11.0\% (w/v) $\mathrm{NaCl}$ (optimum 2.0-4.0\%). The predominant fatty acids were $\mathrm{C}_{18: 1} \omega 7 c$ and $\mathrm{C}_{19: 0}$ cyclo $\omega 8 \mathrm{c}$. The $\mathrm{G}+\mathrm{C}$ content of the genomic DNA was $67.5 \mathrm{~mol} \%$ and the major quinone was Q-10. Phylogenetic analysis based on $16 \mathrm{~S}$ rRNA gene sequences indicated that strain $A D 8^{\top}$ belonged to the genus Citreicella and was most closely related to Citreicella marina CK-I3- $6^{\top}$ within the class Alphaproteobacteria (96.9\% $16 \mathrm{~S}$ rRNA gene sequence similarity). On the basis of phenotypic, chemotaxonomic and phylogenetic analysis, strain $A D 8^{\top}$ represents a novel species within the genus Citreicella, for which the name Citreicella aestuarii sp. nov. is proposed. The type strain is $\mathrm{AD}^{\top}\left(=\mathrm{KACC} 13699^{\top}=\mathrm{DSM}\right.$ $22011^{\top}$ ).
\end{abstract}

The genus Citreicella, a member of the family Rhodobacteraceae in the Alphaproteobacteria, was proposed by Sorokin et al. (2005). Currently, the genus contains only two species, Citreicella thiooxidans (Sorokin et al., 2005; Sorokin et al., 2006) and Citreicella marina (Lai et al., 2010), which were isolated from marine environments: an oxygen-sulfide interface of the Black Sea and a deep-sea sediment of the South-west Indian Ocean Ridge, respectively. Both species are moderately halophilic and have the ability to oxidize thiosulfate to sulfate. Coastal seashores are valuable biological resources as they contain a diversity of micro-organisms and marine animals and play important roles in the restoration of ecosystems. Therefore, efforts have been made in our laboratory to isolate and characterize members of the bacterial community from the coastal seashores of the Yellow Sea in South Korea (Kim et al., 2010a, b; Jin et al., 2011; Jung et al., 2011; Lee et al., 2011). Of note for this study, Yangia pacifica was isolated from a coastal sediment of the East China Sea.

Strain $\mathrm{AD}^{\mathrm{T}}$ was isolated from a surface tidal flat (depth $<3 \mathrm{~cm})$ of the Taean coast $\left(36^{\circ} 49^{\prime} 55.04^{\prime \prime} \mathrm{N} 126^{\circ} 10^{\prime}\right.$ $04.68^{\prime \prime}$ E) of the Yellow Sea, South Korea, during a low tide

The GenBank/EMBL/DDBJ accession number for the $16 \mathrm{~S}$ rRNA gene sequence of strain $\mathrm{AD}^{\top}$ is $\mathrm{FJ} 230833$.

A supplementary figure is available with the online version of this paper. in December 2008, using a previously described procedure with some modifications (Kim et al., 2008). Briefly, the sample was serially diluted in marine broth (MB; Difco), spread on marine agar 2216 (MA; Difco) and incubated at $25{ }^{\circ} \mathrm{C}$ for 5 days. PCR amplification from randomly selected colonies was performed using primers $27 \mathrm{f}$ and $1492 \mathrm{r}$ (Lane, 1991) as described previously (Lu et al., 2006). The resulting $16 \mathrm{~S}$ rRNA gene sequences were compared with GenBank entries using BLASTN searches (http://www.ncbi.nlm.nih.gov/ BLAST/) and the search results were used as a guide to classify the colonies. A novel strain belonging to the genus Citreicella, designated strain $\mathrm{AD}^{\mathrm{T}}$, was selected for further characterization. The isolate was routinely grown aerobically on $\mathrm{MA}$ at $30{ }^{\circ} \mathrm{C}$ for 3 days, except where indicated otherwise, and stored at $-80{ }^{\circ} \mathrm{C}$ in $\mathrm{MB}$ supplemented with $10 \%(\mathrm{v} / \mathrm{v})$ glycerol. C. thiooxidans DSM $10146^{\mathrm{T}}$, C. marina LMG $25230^{\mathrm{T}}$ and Y. pacifica JCM $12573^{\mathrm{T}}$ were purchased from DSMZ (Germany), BCCM/LMG (Belgium) and JCM (Japan), respectively, and used as reference strains for phenotypic characterization and fatty acid analysis.

The 16S rRNA gene amplicon of strain $\mathrm{AD}^{\mathrm{T}}$ was purified and ligated into the pCR2.1 vector using a TOPO cloning kit (Invitrogen), according to the manufacturer's instructions, and sequenced with the M13 reverse and T7 primers of the TOPO cloning kit. The almost-complete 16S rRNA gene 
Table 1. Differential phenotypic characteristics of strain $A D 8^{\top}$ and its closest phylogenetic neighbours

Strains: 1 , Citreicella aestuarii sp. nov. $\mathrm{AD}^{\mathrm{T}}$ (this study); 2, C. marina LMG $25230^{\mathrm{T}}$ (Lai et al., 2010); 3, C. thiooxidans DSM $10146^{\mathrm{T}}$ (Sorokin et al., 2005); 4, Yangia pacifica JCM $12573^{\mathrm{T}}$ (Dai et al., 2006). All strains are positive for catalase, oxidase, alkaline phosphatase $^{\star}$, leucine arylamidase ${ }^{\star}$, hydrolysis of aesculin ${ }^{\star}$ and assimilation of D-glucose ${ }^{\star}, D^{-m a n n i t o l}{ }^{\star}$ and potassium gluconate ${ }^{\star}$. All strains are negative for Gram-staining, indole production*, hydrolysis of gelatin ${ }^{*}$ and Tween $80^{\star}$, assimilation of capric $\operatorname{acid}^{\star}$, arginine dihydrolase $e^{\star}, \beta$ glucosidase $^{\star}, \quad N$-acetyl- $\beta$-glucosaminidase ${ }^{\star}, \alpha$-mannosidase ${ }^{\star}$ and sporulation $^{*}$. OR, Ovoid rods; R, rods; + , positive; $(+)$, weakly positive; -, negative; ND, no data available.

\begin{tabular}{|lcccc|}
\hline Characteristic & $\mathbf{1}$ & $\mathbf{2}$ & $\mathbf{3}$ & $\mathbf{4}$ \\
\hline Morphology & $\mathrm{OR}, \mathrm{R}$ & $\mathrm{R}$ & $\mathrm{OR}$ & $\mathrm{R}$ \\
Motility & + & - & - & + \\
NaCl for growth (\%) & & & & \\
$\quad$ Range & $1-10$ & $1-12$ & $0.5-6.0$ & $1-10$ \\
$\quad$ Optimum & $2-4$ & $2-7$ & 2 & 5 \\
Temperature for growth $\left({ }^{\circ} \mathrm{C}\right)$ & & & & \\
$\quad$ Range & $15-40$ & $4-38$ & $8-35$ & $22-40$ \\
Optimum & $25-30$ & $25-28$ & $25-28$ & 37 \\
Hydrolysis of starch & - & - & + & + \\
Oxidation of thiosulfate & + & + & + & $\mathrm{ND}$ \\
API 20 NE & & & & \\
$\quad$ Nitrate reduction & + & - & - & + \\
Glucose acidification & + & - & - & + \\
Urease & - & + & - & - \\
Assimilation of: & & & & \\
$\quad$ Adipic acid & + & - & + & $(+)$ \\
Malic acid & $(+)$ & + & - & + \\
Trisodium citrate & - & + & + & - \\
Phenylacetic acid & - & - & + & $(+)$ \\
API ZYM & & & & \\
Esterase (C4) & - & + & + & + \\
Esterase lipase (C8) & - & + & + & + \\
Lipase (C14) & - & - & $(+)$ & - \\
Cystine arylamidase & - & $(+)$ & + & + \\
Trypsin & + & - & + & $(+)$ \\
$\alpha$-Chymotrypsin & $(+)$ & - & $(+)$ & - \\
$\quad \alpha$-Galactosidase & $(+)$ & - & + & $(+)$ \\
DNA G+C content (mol\%) & 67.5 & 67.5 & $67.5-69.2$ & 63.3 \\
& & & & \\
\hline
\end{tabular}

${ }^{*}$ Data were taken from this study.

sequence (1384 nt) was compared with sequences available in GenBank using BLAST to determine an approximate phylogenetic affiliation. Sequence similarity values between the isolate and related taxa were evaluated using the Identify program of Eztaxon server (version 2.1; available at http:// 147.47.212.35:8080/; Chun et al., 2007) and aligned using CLUSTAL W (Thompson et al., 1994). Phylogenetic trees using the neighbour-joining and maximum-parsimony algorithms were reconstructed and evaluated by bootstrap analysis based on 1000 resampled datasets using PHYLIP (version 3.6; Felsenstein, 2002). Maximum-likelihood analysis with bootstrap values was performed using RAxML-HPC on ABE (version 7.2.6; Stamatakis et al., 2005) of the Cyberinfrastructure for Phylogenetic Research project (CIPRES, www.phylo.org) at the San Diego Supercomputer Center.

Comparative analysis of $16 \mathrm{~S}$ rRNA gene sequences showed that strain $\mathrm{AD}^{\mathrm{T}}$ was most closely related to $C$. marina $\mathrm{CK}$ I3- $6^{\mathrm{T}}$ and $C$. thiooxidans CHLG $1^{\mathrm{T}}$, with which it shared 96.9 and $95.4 \% 16 \mathrm{~S}$ rRNA gene sequence similarity, respectively. These values are below the threshold generally accepted for species delineation (Rosselló-Mora \& Amann, 2001). The neighbour-joining phylogenetic analysis indicated that strain $\mathrm{AD}^{\mathrm{T}}$ formed a cluster with $C$. marina CK-I3-6 ${ }^{\mathrm{T}}$, with a bootstrap value of $83 \%$, and this was confirmed using the maximum-likelihood and maximumparsimony methods (Fig. 1).

Growth of strain $\mathrm{AD}^{\mathrm{T}}$ was examined on $\mathrm{MA}$ at $4,10,15$, $20,25,30,37,40$ and $45{ }^{\circ} \mathrm{C}$ on $\mathrm{MA}$ and at $\mathrm{pH} 4.5-10.0$ (at intervals of $0.5 \mathrm{pH}$ unit) in $\mathrm{MB}$, with the $\mathrm{pH}$ adjusted using appropriate biological buffers $\left(\mathrm{Na}_{2} \mathrm{HPO}_{4} / \mathrm{NaH}_{2} \mathrm{PO}_{4}\right.$, $\mathrm{pH}<8.0 ; \mathrm{Na}_{2} \mathrm{CO}_{3} / \mathrm{NaHCO}_{3}, \mathrm{pH} 8.0-11.0$; and $\mathrm{Na}_{2} \mathrm{HPO}_{4} /$ $\mathrm{NaOH}, \mathrm{pH}$ 11.0; Gomori, 1955). The $\mathrm{pH}$ was checked after sterilization. Gram-staining was performed using a Gramstain kit (bioMérieux), according to the manufacturer's instructions. Cell morphology, motility and the presence of flagella were studied using phase-contrast microscopy (Axio Lab.A1; Carl Zeiss) and transmission electron microscopy (JEM-1010; JEOL) with 2-day-old cells grown on MA as described previously (Jeon et al., 2004). Growth with 0-15\% $(\mathrm{w} / \mathrm{v}) \mathrm{NaCl}$ (at intervals of $0.5 \%$ ) was determined using nutrient broth (NB; per litre: $3.0 \mathrm{~g}$ beef extract, $5.0 \mathrm{~g}$ peptone) made with modified artificial seawater (per litre: $5.94 \mathrm{~g} \mathrm{MgSO}_{4} \cdot 7 \mathrm{H}_{2} \mathrm{O}, 4.53 \mathrm{~g} \mathrm{MgCl}_{2} \cdot 6 \mathrm{H}_{2} \mathrm{O}, 0.64 \mathrm{~g} \mathrm{KCl}$,

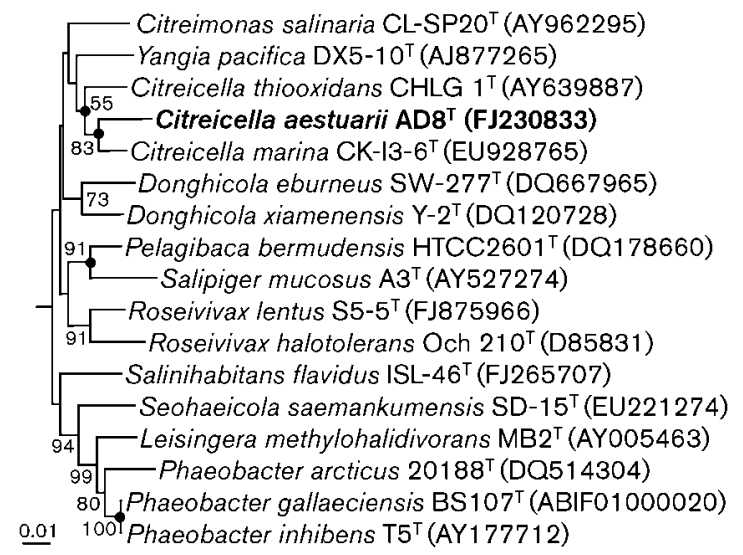

Fig. 1. Neighbour-joining tree based on 16S rRNA gene sequences showing the phylogenetic relationships of strain $\mathrm{AD}^{\top}$ and related taxa. Bootstrap values (>50\%) are shown at branch nodes. Filled circles indicate that the corresponding nodes were also recovered in trees generated with the maximum-parsimony and maximumlikelihood algorithms. Escherichia coli ATCC $11775^{\top}$ (X80725) was used as an outgroup. Bar, 0.01 changes per nucleotide position. 
$1.3 \mathrm{~g} \mathrm{CaCl}_{2}$ ). Hydrolysis of casein, Tween 80 , Tween 20, tyrosine and starch was investigated on R2A agar according to the methods described elsewhere (Lányí, 1987; Smibert \& Krieg, 1994). The oxidation of thiosulfate was tested in $\mathrm{MB}$ supplemented with $10 \mathrm{mM} \mathrm{Na} 2 \mathrm{~S}_{2} \mathrm{O}_{3} \cdot 5 \mathrm{H}_{2} \mathrm{O}$, as described by Chung et al. (2007). Negative controls were prepared with the same medium without inoculation or thiosulfate addition. After aerobic cultivation for 7 days, the concentration of sulfate, the end product of thiosulfate oxidation in $\mathrm{MB}$, was quantified using ion chromatography (ICS-1000; Dionex). Oxidase activity was tested by oxidation of $1 \%$ $(w / v)$ tetramethyl-p-phenylenediamine (Merck) and catalase activity was evaluated by the production of oxygen bubbles in $3 \%(\mathrm{v} / \mathrm{v})$ aqueous hydrogen peroxide (Smibert \& Krieg, 1994). Additional enzyme activities and biochemical features were determined using API ZYM and API $20 \mathrm{NE}$ kits (bioMérieux), according to the manufacturer's instructions except that inocula were prepared by suspending cells in $3 \%(\mathrm{w} / \mathrm{v}) \mathrm{NaCl}$. Incubation was at $30{ }^{\circ} \mathrm{C}$. Anaerobic growth was assessed on MA under 4-10\% $\mathrm{CO}_{2}$ using the GasPak Plus system (BBL) at $30{ }^{\circ} \mathrm{C}$ for 20 days.

Strain $\mathrm{AD}^{\mathrm{T}}$ grew at $15-40{ }^{\circ} \mathrm{C}$ (optimum $25-30{ }^{\circ} \mathrm{C}$ ), at pH 5.0-9.5 (optimum pH 6.0-7.5) and with $1.0-11.0 \%$ $(\mathrm{w} / \mathrm{v}) \mathrm{NaCl}$ (optimum $2.0-4.0 \% \mathrm{NaCl}$ ). Cells were Gramstain-negative, aerobic, ovoid rods or rods $(1.0-1.4 \mu \mathrm{m}$ wide, $1.6-2.2 \mu \mathrm{m}$ long) and motile by means of two lateral flagella on one side (Supplementary Fig. S1; available in IJSEM Online). Motility clearly differentiated strain $\mathrm{AD} 8^{\mathrm{T}}$ from other members of the genus Citreicella (Table 1). Anaerobic growth of strain $\mathrm{AD} 8^{\mathrm{T}}$ was not observed after 20 days at $30{ }^{\circ} \mathrm{C}$ on MA. The physiological and biochemical characteristics of strain $\mathrm{AD}^{\mathrm{T}}$ are given in Table 1 and the species description. Some characteristics of strain $\mathrm{AD} 8^{\mathrm{T}}$ were in accordance with those of members of the genus Citreicella, whereas others differed (Table 1).

Isoprenoid quinones were analysed using HPLC (LC-20A; Shimadzu) with a diode array detector (SPD-M20A; Shimadzu $)$ and a reversed-phase column $(250 \times 4.6 \mathrm{~mm}$; Kromasil, Akzo Nobel) as described elsewhere (Komagata \& Suzuki, 1987). For analysis of fatty acid methyl esters, cells of strain $\mathrm{AD}^{\mathrm{T}}$ and the reference strains, $C$. thiooxidans DSM $10146^{\mathrm{T}}$, C. marina LMG $25230^{\mathrm{T}}$ and Y. pacifica JCM $12573^{\mathrm{T}}$, were harvested from MA after incubation at $30{ }^{\circ} \mathrm{C}$ for 3 days and analysed according to the instructions of the Sherlock Microbial Identification System (MIDI). The DNA G + C content of strain $\mathrm{AD}^{\mathrm{T}}$ was determined using HPLC with a reversed-phase column (GROM-SIL 100 ODS-2FE; GROM) according to the method of Tamaoka \& Komagata (1984).

The major respiratory lipoquinone of strain $\mathrm{AD}^{\mathrm{T}}$ was ubiquinone-10. The major cellular fatty acids ( $>5 \%$ of the total fatty acids) of strain $\mathrm{AD}^{\mathrm{T}}$ were $\mathrm{C}_{18: 1} \omega 7 c(56.95 \%)$, $\mathrm{C}_{19: 0}$ cyclo $\omega 8 c(15.46 \%$ ), summed feature 3 (comprising $\mathrm{C}_{16: 1} \omega 7 c$ and/or iso- $\mathrm{C}_{15: 0}$ 2-OH; $\left.11.39 \%\right)$ and $\mathrm{C}_{16: 0}$ $(10.22 \%)$. Although the overall fatty acid profile of strain $\mathrm{AD}^{\mathrm{T}}$ was similar to those of other members of the genus
Citreicella, the presence or absence of some hydroxy fatty acids clearly distinguished the strain (Table 2). The DNA $\mathrm{G}+\mathrm{C}$ content of strain $\mathrm{AD}^{\mathrm{T}}$ was $67.5 \mathrm{~mol} \%$, which is within the range for the genus Citreicella (67.5-69.2 mol\%).

Therefore, on the basis of physiological, biochemical and phylogenetic analysis, strain $\mathrm{AD} 8^{\mathrm{T}}$ should be placed into a novel species within the genus Citreicella, for which the name Citreicella aestuarii sp. nov. is proposed.

\section{Emended description of the genus Citreicella Sorokin et al. 2006}

The genus description is as given by Sorokin et al. (2005) with the following modifications. Cells are either non-motile short rods without flagella or motile with flagella. Thiosulfate is oxidized to sulfate. The predominant isoprenoid quinone is Q-10. The major fatty acids are $\mathrm{C}_{18: 1} \omega 7 c, \mathrm{C}_{16: 0}$ and $\mathrm{C}_{19: 0}$ cyclo $\omega 8$ c.

Table 2. Cellular fatty acid compositions of strain $A D 8^{\top}$ and its closest phylogenetic neighbours

Strains: 1, Citreicella aestuarii sp. nov. $\mathrm{AD}^{\mathrm{T}} ; 2$, C. marina $\mathrm{LMG}$ $25230^{\mathrm{T}}$; 3, C. thiooxidans DSM $10146^{\mathrm{T}}$; 4, Yangia pacifica JCM $12573^{\mathrm{T}}$. All data were taken from this study after growth on marine agar at $30{ }^{\circ} \mathrm{C}$ for 3 days. Fatty acids accounting for $<0.5 \%$ in all strains are not shown. Major components $(>10.0 \%)$ are highlighted in bold. tr, Trace amount $(<0.5 \%)$; , not detected.

\begin{tabular}{|c|c|c|c|c|}
\hline Fatty acid (\%) & 1 & 2 & 3 & 4 \\
\hline \multicolumn{5}{|l|}{ Saturated } \\
\hline $\mathrm{C}_{10: 0}$ & - & 0.50 & 2.77 & - \\
\hline $\mathrm{C}_{15: 0}$ & - & 0.68 & - & - \\
\hline $\mathrm{C}_{16: 0}$ & 10.22 & 10.16 & 28.02 & 13.34 \\
\hline $\mathrm{C}_{17: 0}$ & - & 0.51 & $\operatorname{tr}$ & 0.74 \\
\hline $\mathrm{C}_{18: 0}$ & - & - & - & 0.75 \\
\hline \multicolumn{5}{|l|}{ Unsaturated } \\
\hline $\mathrm{C}_{17: 0}$ cyclo & - & 0.66 & 3.3 & - \\
\hline $\mathrm{C}_{17: 1} \omega 8 c$ & - & 0.60 & - & - \\
\hline 11-Methyl $\mathrm{C}_{18: 1} \omega 7 c$ & 2.29 & 0.97 & - & 3.31 \\
\hline $\mathrm{C}_{18: 1} \omega 7 c$ & 56.95 & 62.31 & 24.84 & 70.42 \\
\hline $\mathrm{C}_{19: 0}$ cyclo $\omega 8 c$ & 15.46 & 9.86 & 17.98 & 3.95 \\
\hline $\mathrm{C}_{20: 2} \omega 6,9 c$ & 1.28 & - & - & - \\
\hline \multicolumn{5}{|l|}{ Hydroxyl } \\
\hline $\mathrm{C}_{10: 0} 3-\mathrm{OH}$ & 2.41 & - & - & - \\
\hline $\mathrm{C}_{12: 0} 3-\mathrm{OH}$ & - & $\operatorname{tr}$ & 4.13 & 2.52 \\
\hline $\mathrm{C}_{12: 1} 3-\mathrm{OH}$ & - & 4.32 & - & - \\
\hline \multicolumn{5}{|l|}{ Summed features ${ }^{\star}$} \\
\hline 3 & 11.39 & 7.81 & 17.47 & 4.96 \\
\hline 7 & - & $\operatorname{tr}$ & 0.52 & - \\
\hline
\end{tabular}

${ }^{*}$ Summed features represent two or three fatty acids that cannot be separated by the Microbial Identification System. Summed feature 3 consisted of $\mathrm{C}_{16: 1} \omega 7 c$ and/or iso- $\mathrm{C}_{15: 0}$ 2-OH. Summed feature 7 consisted of one or more of $\mathrm{C}_{19: 0}$ cyclo $\omega 10 c, \mathrm{C}_{19: 1} \omega 6 c$ and equivalent chain-length 18.846 . 


\section{Description of Citreicella aestuarii sp. nov.}

Citreicella aestuarii (a.es.tu.a'ri.i. L. gen. n. aestuarii of a tidal flat, from where the organism was isolated).

Colonies on MA are pale beige, convex, round and nonpigmented with entire margins. Cells are Gram-stainnegative, strictly aerobic rods or ovoid rods $(1.0-1.4 \mu \mathrm{m}$ wide and 1.6-2.2 $\mu \mathrm{m}$ long). Motile by means of two lateral flagella on one side of a cell. Growth occurs at $15-40{ }^{\circ} \mathrm{C}$ (optimum $25-30{ }^{\circ} \mathrm{C}$ ) and $\mathrm{pH}$ 5.0-9.5 (optimum $\mathrm{pH}$ 6.07.5). Moderately halophilic; grows with $1.0-11.0 \%(\mathrm{w} / \mathrm{v})$ $\mathrm{NaCl}$ (optimum 2.0-4.0\%). Oxidase- and catalase-positive. Thiosulfate is oxidized to sulfate. Nitrate is reduced to nitrite, but nitrogen gas is not produced. With API $20 \mathrm{NE}$, positive for glucose acidification, assimilation of D-glucose, D-mannitol, gluconate and adipic acid and hydrolysis of aesculin and tyrosine, weakly positive for assimilation of $\mathrm{N}$ acetylglucosamine, maltose and malic acid, but negative for indole production, arginine dihydrolase, assimilation of Larabinose, D-mannose, capric acid, trisodium citrate and phenylacetic acid and hydrolysis of urea, gelatin, Tweens 20 and 80, casein and starch. With API ZYM, positive for alkaline phosphatase, leucine arylamidase, valine arylamidase, trypsin, acid phosphatase and naphthol-AS-BIphosphohydrolase activities, weakly positive for $\alpha$-chymotrypsin and $\alpha$-galactosidase, but negative for esterase (C4), esterase lipase (C8), lipase (C14), cystine arylamidase, $\beta$ galactosidase, $\beta$-glucuronidase, $\alpha$ - and $\beta$-glucosidase, $N$ acetyl $-\beta$-glucosaminidase, $\alpha$-fucosidase and $\alpha$-mannose. The major isoprenoid quinone is Q-10. The major cellular fatty acids $\left(>10 \%\right.$ of total) are $\mathrm{C}_{18: 1} \omega 7 c, \mathrm{C}_{19: 0}$ cyclo $\omega 8 c$, summed feature 3 (comprising $\mathrm{C}_{16: 1} \omega 7 \mathrm{c}$ and/or iso- $\mathrm{C}_{15: 0}$ 2-OH) and $\mathrm{C}_{16: 0}$. The DNA G $+\mathrm{C}$ content of the type strain is $67.5 \mathrm{~mol} \%$ (HPLC).

The type strain is $\mathrm{AD}^{\mathrm{T}}\left(=\mathrm{KACC} 13699^{\mathrm{T}}=\mathrm{DSM} 22011^{\mathrm{T}}\right.$ ), which was isolated from a tidal flat of the Taean coast in South Korea.

\section{Acknowledgements}

This work was carried out with the support of the Cooperative Research Program for Agriculture Science \& Technology Development of the Rural Development Administration (project no. J007451) and the National Research Foundation of Korea of the Korean Government (MEST), Republic of Korea (grant no. 2009-0071880).

\section{References}

Chun, J., Lee, J.-H., Jung, Y., Kim, M., Kim, S., Kim, B.-K. \& Lim, Y.-W. (2007). EzTaxon: a web-based tool for the identification of prokaryotes based on $16 \mathrm{~S}$ ribosomal RNA gene sequences. Int J Syst Evol Microbiol 57, 2259-2261.

Chung, B. S., Ryu, S. H., Park, M., Jeon, Y., Chung, Y. R. \& Jeon, C. O. (2007). Hydrogenophaga caeni sp. nov., isolated from activated sludge. Int J Syst Evol Microbiol 57, 1126-1130.

Dai, X., Wang, B. J., Yang, Q. X., Jiao, N. Z. \& Liu, S. J. (2007). Yangia pacifica gen. nov., sp. nov., a novel member of the Roseobacter clade from coastal sediment of the East China Sea. Int J Syst Evol Microbiol 56, 529-533.

Felsenstein, J. (2002). PHYLIP (phylogeny inference package), version 3.6a. Distributed by the author. Department of Genome Sciences, University of Washington, Seattle, USA.

Gomori, G. (1955). Preparation of buffers for use in enzyme studies. Methods Enzymol 1, 138-146.

Jeon, C. O., Park, W., Ghiorse, W. C. \& Madsen, E. L. (2004). Polaromonas naphthalenivorans sp. nov., a naphthalene-degrading bacterium from naphthalene-contaminated sediment. Int J Syst Evol Microbiol 54, 93-97.

Jin, H. M., Lee, H. J., Kim, J. M., Park, M. S., Lee, K. \& Jeon, C. O. (2011). Litorimicrobium taeanense gen. nov., sp. nov., isolated from a sandy beach. Int J Syst Evol Microbiol 61, 1392-1396.

Jung, J. Y., Kim, J. M., Jin, H. M., Kim, S. Y., Park, W. \& Jeon, C. O. (2011). Litorimonas taeanensis gen. nov., sp. nov., isolated from a sandy beach. Int J Syst Evol Microbiol 61, 1534-1538.

Kim, J. M., Le, N. T., Chung, B. S., Park, J. H., Bae, J.-W., Madsen, E. L. \& Jeon, C. O. (2008). Influence of soil components on the biodegradation of benzene, toluene, ethylbenzene, and $o$-, $m$-, and p-xylenes by the newly isolated bacterium Pseudoxanthomonas spadix BD-a59. Appl Environ Microbiol 74, 7313-7320.

Kim, J. M., Lee, S. H., Jung, J. Y. \& Jeon, C. O. (2010a). Marinobacterium lutimaris sp. nov., isolated from a tidal flat. Int J Syst Evol Microbiol 60, 1828-1831.

Kim, J. M., Jung, J. Y., Chae, H. B., Park, W. \& Jeon, C. O. (2010b). Hwanghaeicola aestuarii gen. nov., sp. nov., a moderately halophilic bacterium isolated from a tidal flat of the Yellow Sea. Int J Syst Evol Microbiol 60, 2877-2881.

Komagata, K. \& Suzuki, K. (1987). Lipid and cell-wall analysis in bacterial systematics. Methods Microbiol 19, 161-207.

Lai, Q., Qiao, N., Wu, C., Sun, F., Yuan, J. \& Shao, Z. (2010). Stappia indica sp. nov., isolated from deep seawater of the Indian Ocean. Int $J$ Syst Evol Microbiol 60, 733-736.

Lane, D. J. (1991). 16S/23S rRNA sequencing. In Nucleic Acid Techniques in Bacterial Systematics, pp. 115-175. Edited by E. Stackebrandt \& M. Goodfellow. Chichester: Wiley.

Lányí, B. (1987). Classical and rapid identification methods for medically important bacteria. Methods Microbiol 19, 1-67.

Lee, S. H., Shim, J. K., Kim, J. M., Choi, H.-K. \& Jeon, C. O. (2011). Henriciella litoralis sp. nov., isolated from a tidal-flat of the Yellow Sea, and transfer of Maribaculum marinum Lai et al. 2009 to the genus Henriciella as Henriciella aquimarina nom. nov. and emended description of the genus Henriciella. Int J Syst Evol Microbiol 61, 722-727.

Lu, S., Park, M., Ro, H.-S., Lee, D. S., Park, W. \& Jeon, C. O. (2006). Analysis of microbial communities using culture-dependent and culture-independent approaches in an anaerobic/aerobic SBR reactor. J Microbiol 44, 155-161.

Rosselló-Mora, R. \& Amann, R. (2001). The species concept for prokaryotes. FEMS Microbiol Rev 25, 39-67.

Smibert, R. M. \& Krieg, N. R. (1994). Phenotypic characterization. In Methods for General and Molecular Bacteriology, pp. 607-654. Edited by P. Gerhardt. Washington, DC: American Society for Microbiology.

Sorokin, D. Y., Tourova, T. P. \& Muyzer, G. (2005). Citreicella thiooxidans gen. nov., sp. nov., a novel lithoheterotrophic sulfuroxidizing bacterium from the Black Sea. Syst Appl Microbiol 28, 679687.

Sorokin, D. Y., Tourova, T. P. \& Muyzer, G. (2006). Citreicella thiooxidans gen. nov., sp. nov. In List of New Names and New 
Combinations Previously Effectively, but not Validly, Published, Validation List no. 107. Int J Syst Evol Microbiol 56, 1-6.

Stamatakis, A., Ott, M. \& Ludwig, T. (2005). RAxML-OMP: an efficient program for phylogenetic inference on SMPs. In Proceedings of 8th International Conference on Parallel Computing Technologies (PaCT2005). Lecture Notes in Computer Science, 3506, 288-302, Springer Verlag.
Tamaoka, J. \& Komagata, K. (1984). Determination of DNA base composition by reverse-phase high-performance liquid chromatography. FEMS Microbiol Lett 25, 125-128.

Thompson, J. D., Higgins, D. G. \& Gibson, T. J. (1994). CLUSTAL W: improving the sensitivity of progressive multiple sequence alignment through sequence weighting, position-specific gap penalties and weight matrix choice. Nucleic Acids Res 22, 4673-4680. 